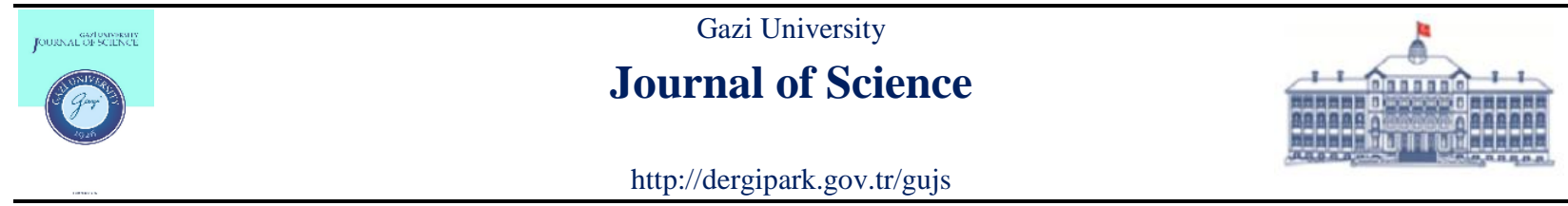

\title{
Antioxidant and Cytotoxic Activity Studies in Series of Higher Amino Acid Schiff Bases
}

\author{
Ozlem OZDEMIR $^{1, *(D)}$, Perihan GURKAN ${ }^{(1)}$, Yaprak Dilber SIMAY DEMIR $^{2}$ (D), Mustafa ARK AD $^{\text {(D) }}$ \\ ${ }^{1}$ Gazi University, Faculty of Science, 06500, Ankara, Turkey \\ ${ }^{2}$ Hitit University, Faculty of Medicine, 19040, Çorum, Turkey \\ ${ }^{3}$ Gazi University, Faculty of Pharmacy, 06330, Ankara, Turkey \\ Highlights \\ - DPPH scavenging ability of the higher amino acid Schiff bases was investigated. \\ - In vitro cytotoxicity of these Schiff bases was tested against cancer and human normal cells. \\ - Schiff base $2 \mathrm{~b}$ killed 90 percent of MCF-7 cells at concentration of $100 \mu \mathrm{M}$.
}

Article Info

Received: 03/12/2019

Accepted: 16/03/2020

Keywords

Amino Acid Schiff bases

Radical Scavenging

Cytotoxicity

Doxorubicin

\begin{abstract}
In this work, the antioxidant activity of the higher amino acid Schiff bases, which were prepared as the monosodium salts $(\mathbf{1 a}-\mathbf{3 a})$ and the neutral forms $(\mathbf{1 b}-\mathbf{3 b})$ was determined by DPPH scavenging assay. In pure $\mathrm{MeOH}$ solution, the scavenging ability of Schiff bases 1a-3a were higher than 1b-3b, but lower than ascorbic acid. The activity followed the order $3(a, b)>2(a, b)$ $>1(a, b)$. On the other hand, Schiff bases 2a and 3a behaved as the most effective scavengers of the DPPH radical in methanol-water mixture (v:v, 1:3). And, they were found to be have lower SC50 values in this mixture compared to pure methanol. In vitro cytotoxicity of these Schiff bases was studied against human cervical cancer cells (HeLa), human breast adenocarcinoma cells (MCF-7), and human normal embryonic kidney cells (HEK293). For HeLa cell line, Schiff bases 1a-3a exhibited a littlle high activity than $\mathbf{1 b}$, but very low activity than doxorubicin. Schiff bases $\mathbf{2 b}$ and $\mathbf{3 b}$ had no cytotoxicity against HeLa cell. For MCF-7 cell line, Schiff bases 1a, 3a, 1b and 3b nearly were inactive at $100 \mu \mathrm{M}$, whereas $\mathbf{2 a}$ increased cell proliferation in the all tested concentration range. Differently, Schiff base $\mathbf{2 b}$ showed the highest cytotoxicity and killed 90 percent of MCF-7 cells at concentration of $100 \mu \mathrm{M}$. For HEK-293, doxorubicin was strongly cytotoxic. Despite this, Schiff bases 1a, 3a and 3b were inactive, whereas the others showed little weak toxicity.
\end{abstract}

\section{INTRODUCTION}

Endogenous reactive oxygen species (ROS: $\mathrm{O}, \mathrm{OH}, \mathrm{O}_{2}{ }^{-}$and $\mathrm{H}_{2} \mathrm{O}_{2}$ ) are naturally formed in the life of aerobic organism. Exogenous species occur as a result of toxic agents, drugs or different lifestyle choices like as smoking and burnt food, etc. [1]. The excess ROS production becomes toxic, and this damages structure and function of biological molecules like as lipids, carbohydrates, proteins, DNA and nucleic acids in body metabolism, and causes degenerative diseases such as aging, diabetes, inflammatory, cardiovascular, autoimmune and cancer [2-4]. Also, neurodegenerative diseases as Alzheimer's and Parkinson's have been found to be related to an increase in quantity of ROS inside the human body [5]. Antioxidants react with these free radicals, terminate their chain reactions and minimize their harmful effects in metabolism [6]. They also protect the quality of food stuffs [7]. Natural antioxidants isolated from aromatic plants are flavonoids, tannins, phenolic acids, alkaloids, chlorophyll derivatives, carotenoids and tocopherols. There are also some synthetic phenolic antioxidants as butylated hydroxy-toluene, butylated hydroxy-anisole and tert-butylhydroquinone [8]. 
Cancer is a group of diseases which is characterized by uncontrolled cell proliferation and disruption of vital tissues [9]. The mutation in DNA is the main reason for all common cancer types. Otherwise, oxidative stress due to the excess production of ROS has a significant role in carcinogenesis [10]. In the treatment of cancer, different methods such as chemotherapy, radiotherapy, immunotherapy etc. are utilized. Recently, antioxidants have been reported to induce apoptosis process in the cancer cells by decreasing the cellular ROS levels [11]. Among them chemotherapy is one of the most common method, and antineoplastic drugs are used in the chemotherapy of tumors. Metal-based drugs cisplatin and its analogues (nedaplatin, lobaplatin and heptaplatin) are highly effective drugs, which are succesfully utilized for the treatment of solid tumors as well as testicles, ovarian, melanoma and breast [12-13]. Doxorubicin is also one of anticancer antibiotics. It is generally used for lung and esophageal carcinoma, osteosarcoma, Hodgkin and NonHodgkin lymphoma [14]. But, the usage of all these chemotherapeutics are often limited by several types of side effects such as dose-limiting toxicity, nephrotoxicity, neurotoxicity, ototoxicity, and cardiotoxicity [15-16]. The other important problem is the occurrence of resistance to drugs in tumor cells during chemotherapy [17]. For these reasons, there is a need for new drugs with higher activity and less toxicity than present antineoplastic drugs, and thus the design of new agents has become the main aim of research in medicinal chemistry.

Amino acid Schiff bases obtained from salicylaldehyde and $\alpha$-amino acids, as glycine, alanine, phenylalanine, valine, histidine, and etc. have been extensively synthesized because of being model compounds of a coenzyme of vitamin B6 [18-22]. These Schiff bases are one of the class of compounds possessing a broad spectrum of pharmacological activities such as antibacterial [23], antifungal [24], antiinflammatory [25], enzyme inhibition [26] and antioxidant activity [27]. Their metal complexes containing platinum [28], ruthenium [29], palladium [30], nickel [31] and lanthanum [32] have shown to be promising good antitumor, serum albumin and DNA-binding activities. In recent years, researchers have reported a novel series of the Schiff bases derived from alkanoic acid molecules $\left[\mathrm{H}_{2} \mathrm{~N}-\left(\mathrm{CH}_{2}\right)_{n}-\mathrm{COOH}\right.$, where $\left.\mathrm{n} \geq 3\right]$ [33-35]. But, information on their activities as antioxidant and antitumor is still rare.

\section{MATERIAL METHOD}

\subsection{Materials}

2,2-diphenyl-1-picrylhydrazyl (DPPH) (Aldrich), L-ascorbic acid (Carlo Erba), Dulbecco's Modified Eagle's Medium (DMEM) (Gibco), fetal bovine serum (FBS) (Gibco), penisilin-streptomisin (PAA), doksorubicin (Tocris) were used without purification. Absolute methanol and ethanol were purchased from Sigma. Two different human carcinoma cell lines (HeLa, human cervical cancer and MCF-7, human breast adenocancer) were obtained from Molecular Biology and Genetic Department of Bilkent University and Biochemistry Department of Middle East Technical University, respectively. Normal human cell line (HEK293, human embryonic kidney cell) was obtained from Biotechnology Institute of Ankara University.

\subsection{Synthesis of the Higher Amino Acid Schiff Bases}

The monosodium-Schiff bases (1a-3a) and the neutral-Schiff bases (1b-3b) were synthesized and characterized in our previous work [36].

\subsection{DPPH Radical Scavenging Activity}

The activity was evaluated by following the reported method [37]:

Sample solutions $(2 \mathrm{mg} / \mathrm{mL})$ of the monosodium-Schiff bases were prepared separately in doubly distilled water and methanol. Under same condition, $2 \mathrm{mg}$ of the neutral-Schiff bases was dissolved in $1 \mathrm{~mL}$ of methanol. And, a solution of DPPH $(0.1 \mathrm{mM})$ was prepared in methanol. A volume of $1 \mathrm{~mL}$ of DPPH was added to different volumes of sample solutions of compounds $(2 \mathrm{mg} / \mathrm{mL})$, and it made up to a final volume of $4 \mathrm{~mL}$ using solvent. The tubes was shaken vigorously and kept in dark at room temperature. After 30 min, the absorbance of the samples was recorded at $517 \mathrm{~nm}$ by using Analytik Jena Specord 200 spectrophotometer in steps of $1 \mathrm{~nm}$ using a 1-cm-thick quartz cell. Methanol was used for the baseline 
correction. DPPH solution and ascorbic acid were used as control and standard. All determinations were performed in triplicate.

DPPH scavenging activity was calculated by using Equation (1):

$\% D P P H$ scavenging $=(A 0-A 1) /_{A 0} \times 100$

where $\mathrm{A}_{0}$ and $\mathrm{A}_{1}$ are the absorbance of control and sample solution. \% scavenging was plotted against the different concentrations used, and $\mathrm{SC}_{50}$ value was calculated from the graph. $\mathrm{SC}_{50}(\mathrm{mg}$ sample per $\mathrm{mL})$ is the concentration of the samples that causes $50 \%$ scavenging of DPPH radical.

\subsection{Cell Culture}

Three different human cell lines were cultured in DMEM supplemented with 10\% FBS, 1\% penicillinstreptomycin. Cells were maintained at $37{ }^{\circ} \mathrm{C}$ in a humidified atmosphere of $5 \% \mathrm{CO}_{2}$ (Sanyo) in air. The culture medium was changed every 2 days until the cell culture reached $70-80 \%$ confluence. When cells reached 70-80\% confluence, they were treated with Schiff bases and doxorubicin at varying concentrations. At the end of two days, three different areas were chosen randomly, and an image of the cells was taken using phase-contrast microscope (Leica). Blebbing and normal cells were counted in the photographs by microscope camera (Leica DFC $420 \mathrm{C}$ ). The percentage of cells with blebs was calculated by dividing the number of cells with blebs by the total number of cells.

\subsection{Real Time Monitoring of Cytotoxicity}

An xCELLigence Real-Time Cell Analyzer (RTCA) DP system (Roche) was used to monitor the viability and migration of cells (HeLa, MCF-7 and HEK293), as previously described [38]. Briefly, $8 \times 10^{3}-1 \times$ $10^{4}$ cells were plated per well of an E-plate. Cell growth and/or viability was monitored every 15 min for $20 \mathrm{~h}$. After $20 \mathrm{~h}$, the existing medium was replaced with fresh medium (DMEM + 10\% FBS + 1\% penisilinstreptomisin). When Cell Index was in the range of 1-1.5, the cells were incubated with Schiff bases and doxorubicin at varying concentrations. As an indicator of cell detachment, the cell index was recorded continuously for $48 \mathrm{~h}$ and analyzed by RTCA DP system. HeLa, MCF-7 and HEK293 cells were monitored for another $48 \mathrm{~h}$, as a control.

\subsection{Statistical Analysis}

All values were expressed as the mean \pm s.e.m and analyzed by Student's $t$ test, and ANOVA. $\mathrm{P}<0.05$ was considered statistically significant.

\section{RESULTS AND DISCUSSION}

\subsection{DPPH Assay}

To evaluate the antioxidant activity of Schiff bases (Figure 1), they reacted with a stable DPPH radical in pure methanol and methanol-water (v:v, 1:3) solutions. The reaction was monitored by the decrease in absorbance of DPPH at $517 \mathrm{~nm}$. The percentages of DPPH radical scavenging were tabulated in Tables 1 and 2 . 
<smiles>CC(=O)CCCN=Cc1cc([N+](=O)[O-])ccc1O</smiles><smiles>[X]C(=O)CCCCN=CC(C)=CC(=C)C#N</smiles>

\begin{tabular}{|cc|}
\hline $\mathrm{X}$ & Compound \\
$\mathrm{Na}$ & $(\mathbf{1 a - 3 a})$ \\
$\mathrm{H}$ & $(\mathbf{1 b - 3 b})$ \\
\hline
\end{tabular}<smiles>CC(=O)CCCCCN=Cc1cc([N+](=O)[O-])ccc1O</smiles>

Figure 1. The structures of the higher amino acid Schiff bases

As can be seen in Table 1, when the concentration of the compounds was increased, the scavenging percentage was also increased, which points out the lower $\mathrm{SC}_{50}$ value. Schiff bases (1a-3a) showed good antioxidant activities of $\mathrm{SC}_{50}$ values $(5.04,3.79$ and $3.34 \mu \mathrm{M})$ in $\mathrm{MeOH}$ solution, comparable with that of $\mathbf{1 b}-\mathbf{3 b}(9.05,7.52$ and $4.82 \mu \mathrm{M})$. This indicated that the scavenging potency of the neutral-Schiff bases is lower than the monosodium-Schiff bases, despite the activity is only dependent on the presence of hydroxyl group. It may be explained by an electron-withdrawing effect of carboxyl group in $\mathbf{1 b}-\mathbf{3 b}$ [39]. The scavenging activity for Schiff bases decreased in the order: $\mathbf{3 a}>\mathbf{2 a}>\mathbf{1 a}$ and $\mathbf{3 b}>\mathbf{2 b}>\mathbf{1 b}$. This may be due to the increasement of a number of an electron donating $\left(\mathrm{CH}_{2}\right)$ group in structure, which increase the resonance ability and radical scavenging potency of phenoxyl radical. This result may be associated to the lipophilic character of alkyl chain. Porter suggested that lipophilic antioxidants show more antioxidant activity in polar mediums [40]. Besides, it has been reported that monophenols hindered sterically by alkyl groups have a high activity [41]. Under the same test conditions, $\mathrm{SC}_{50}$ value of ascorbic acid was found to be $<0.14 \mu \mathrm{M}$. Different $\mathrm{SC}_{50}$ values were presented in literature for ascorbic acid in $\mathrm{MeOH}$ solution such as $11.8 \mu \mathrm{M}$ [42] and $46.81 \mu \mathrm{M}$ [43], which were related to used DPPH concentration. $\mathrm{SC}_{50}$ values of six Schiff bases were higher than ascorbic acid corresponding to their medium antiradical efficiency. It may be resulted from strong electron-withdrawing effect of nitro group in Schiff bases. Because nitro group can cause the poor resonance in phenoxyl radical and decrease the scavenging potency [44].

Table 1. DPPH scavenging activity of all the Schiff bases in $\mathrm{MeOH}$

\begin{tabular}{|l|l|l|l|l|l|l|l|l|}
\hline \multirow{2}{*}{ Compound } & \multicolumn{7}{|c|}{ \% Scavenging average } & \multicolumn{1}{|c|}{$\begin{array}{l}\mathrm{SC}_{50} \mathrm{mg} / \mathrm{mL} \\
(\mu \mathrm{M})\end{array}$} \\
\cline { 2 - 9 } & \multicolumn{7}{|c|}{ Concentration $(\mathrm{mg} / \mathrm{mL})^{\mathrm{b}}$} \\
\cline { 2 - 9 } & $0.10^{\mathrm{b}}$ & 0.20 & 0.40 & 0.60 & 0.80 & 1.20 & 1.60 & \\
\hline 1a & $30.05^{\mathrm{a}}$ & 32.69 & 36.12 & 39.10 & 41.56 & 44.53 & 54.96 & $1.38(5.04)$ \\
& \pm 0.28 & \pm 0.31 & \pm 0.07 & \pm 0.32 & \pm 0.44 & \pm 0.50 & \pm 0.52 & \\
\hline 2a & 28.78 & 31.60 & 36.71 & 40.45 & 46.22 & 51.43 & 59.61 & $1.09(3.79)$ \\
& \pm 0.84 & \pm 0.72 & \pm 0.79 & \pm 0.72 & \pm 0.32 & \pm 0.33 & \pm 0.62 & \\
\hline 3a & 29.29 & 31.92 & 38.73 & 42.73 & 46.42 & 53.64 & 61.47 & $1.01(3.34)$ \\
& \pm 0.35 & \pm 0.11 & \pm 0.22 & \pm 0.26 & \pm 0.41 & \pm 0.21 & \pm 0.18 & \\
\hline 1b & 24.46 & 26.02 & 28.34 & 30.35 & 32.42 & 37.40 & 42.24 & $2.28(9.05)$ \\
& \pm 0.61 & \pm 0.02 & \pm 0.61 & \pm 0.23 & \pm 0.22 & \pm 0.14 & \pm 0.76 & \\
\hline 2b & 25.72 & 27.49 & 29.70 & 32.22 & 35.29 & 39.17 & 45.29 & $2.00(7.52)$ \\
& \pm 0.25 & \pm 0.06 & \pm 0.25 & \pm 0.12 & \pm 0.31 & \pm 0.11 & \pm 0.57 & \\
\hline 3b & 26.55 & 30.92 & 33.92 & 37.86 & 41.09 & 47.29 & 53.71 & $1.35(4.82)$ \\
& \pm 0.24 & \pm 0.46 & \pm 0.77 & \pm 0.19 & \pm 0.08 & \pm 0.57 & \pm 0.50 & \\
\hline Ascorbic & $0.025^{\mathrm{b}}$ & 0.050 & 0.10 & 0.15 & 0.20 & 0.30 & 0.40 & \\
\cline { 2 - 9 } acid & $59.52^{\mathrm{a}}$ & 60.53 & 61.27 & 63.01 & 63.91 & 66.57 & 69.09 & $<0.025$ \\
& \pm 0.18 & \pm 0.08 & \pm 0.33 & \pm 0.01 & \pm 0.25 & \pm 0.53 & \pm 0.24 & $(<0.14)$ \\
\hline
\end{tabular}


In an aqueous methanolic solution, $\mathrm{SC}_{50}$ values of the monosodium-Schiff bases (1a-3a) and ascorbic acid were determined as $2.85 \mu \mathrm{M}, 2.15 \mu \mathrm{M}, 1.85 \mu \mathrm{M}$ and $2.61 \mu \mathrm{M}$, respectively. The scavenging activity followed the order: 3a $>\mathbf{2 a}>$ ascorbic acid $>\mathbf{1 a}$. From Tables 1 and 2, it was clear that Schiff bases (1a-3a) have lower $\mathrm{SC}_{50}$ values in methanol-water mixture in comparison to pure methanol. It is well known that radical scavenging mechanism is influenced by the solvent polarity and its hydrogen bonding ability [8]. The strong intermolecular hydrogen bonding between methanol and water molecules could facilitate the interaction between Schiff bases and DPPH radical, and enhance the intermolecular hydrogen transfer from phenol moiety of compound to radical. The comparison of $\mathrm{SC}_{50}$ values of compounds in pure $\mathrm{MeOH}$ and aqueous methanolic solution was given in Figure 2.

Table 2. DPPH scavenging activity of the monosodium-Schiff bases in MeOH-water mixture (v:v, 1:3)

\begin{tabular}{|l|l|l|l|l|l|l|l|l|}
\hline \multirow{3}{*}{ Compound } & \multicolumn{7}{|c|}{ \% Scavenging average ${ }^{\mathrm{a}}$} & \multicolumn{1}{|c|}{$\begin{array}{l}\mathrm{SC}_{50} \mathrm{mg} / \mathrm{mL} \\
(\mu \mathrm{M})\end{array}$} \\
\cline { 2 - 9 } & $0.10^{\mathrm{b}}$ & 0.20 & 0.40 & 0.60 & 0.80 & 1.20 & 1.60 & \\
\hline \multirow{2}{*}{ aa } & $33.03^{\mathrm{a}}$ & 36.49 & 42.52 & 46.99 & 52.08 & 59.92 & 66.87 & $0.78(2.85)$ \\
& \pm 0.02 & \pm 0.54 & \pm 0.56 & \pm 0.08 & \pm 0.12 & \pm 0.52 & \pm 0.10 & \\
\hline 2a & 39.35 & 41.37 & 45.96 & 50.41 & 54.06 & 62.74 & 67.77 & $0.62(2.15)$ \\
& \pm 0.53 & \pm 0.40 & \pm 0.36 & \pm 0.16 & \pm 0.08 & \pm 0.76 & \pm 0.90 & \\
\hline 3a & 40.25 & 42.50 & 46.52 & 51.98 & 55.50 & 63.64 & 68.21 & $0.56(1.85)$ \\
& \pm 0.39 & \pm 0.04 & \pm 0.14 & \pm 0.17 & \pm 0.26 & \pm 0.23 & \pm 0.39 & \\
\hline Ascorbic & $0.025^{\mathrm{b}}$ & 0.050 & 0.10 & 0.15 & 0.20 & 0.30 & 0.40 & \\
\cline { 2 - 9 } acid & $39.89^{\mathrm{a}}$ & 40.47 & 42.17 & 43.21 & 44.91 & 46.66 & 48.00 & $0.46(2.61)$ \\
& \pm 0.36 & \pm 0.62 & \pm 0.14 & \pm 0.31 & \pm 0.26 & \pm 0.23 & \pm 0.18 & \\
\hline
\end{tabular}

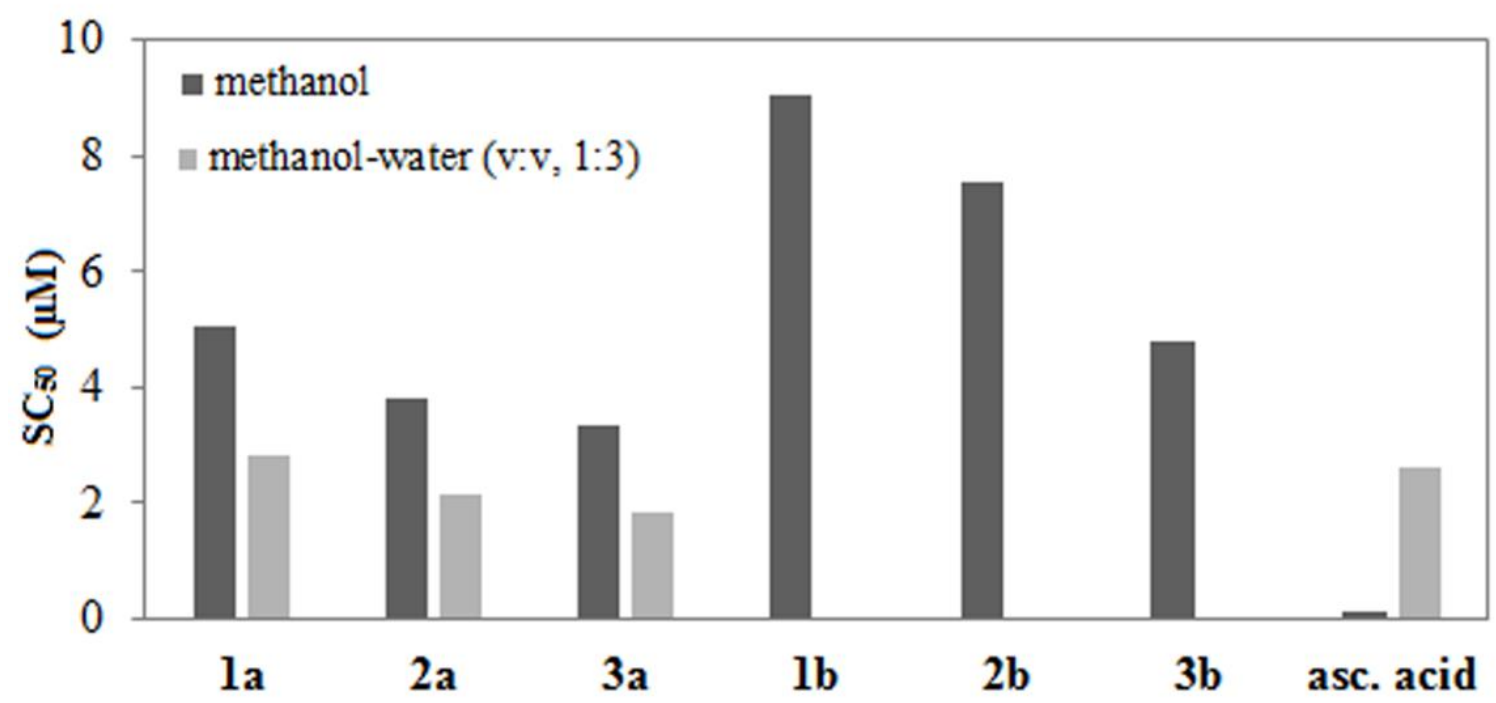

Figure 2. Comparable chart for $S C_{50}$ values $(\mu M)$ of Schiff bases. The set concentration of DPPH was 25 $\mu M$. Data are the means of three independent experiments

The obtained DPPH assay results indicated that Schiff bases 1a-3a were found to be more active than 1b3b, but less active than ascorbic acid in pure $\mathrm{MeOH}$ solution. The activity increased with an increasement of alkyl chain in series, and it followed the order $3(\mathbf{a}, \mathbf{b})>2(\mathbf{a}, \mathbf{b})>1(\mathbf{a}, \mathbf{b})$. Besides, the scavenge ability of the monosodium-Schiff bases was in the order: $\mathbf{3 a}>\mathbf{2} \mathbf{a}>$ asc. acid $>\mathbf{1 a}$ in an aqueous methanolic solution.

Literature survey has showed that o-vanillylidene-L-histidine Schiff base and its copper(II) complex exhibited good scavenging ability in methanol with $\mathrm{SC}_{50}$ values of $0.6 \mathrm{mg} / \mathrm{mL}$ and $0.3 \mathrm{mg} / \mathrm{mL}$ [45]. Some sodium-Schiff bases derived from alanine, valine and phenylalanine were found to be have $\mathrm{SC}_{50}$ value of $1.38 \mathrm{mg} / \mathrm{mL}, 3.11 \mathrm{mg} / \mathrm{mL}$ and $0.45 \mathrm{mg} / \mathrm{mL}$ in methanol, respectively [18]. A novel Schiff base including s-allyl cystiene and methionine had lower $\mathrm{SC}_{50}$ value $(52.5 \mu \mathrm{g} / \mathrm{mL})$, which was related to a higher radical 
scavenging activity [46]. Oxo-vanadium complexes of $\mathrm{N}$-salicyldene-amino acid sodium sulfonate ligands (amino acid = alanine, leucine, glycine and tryptophan) were also reported to have high scavenging potential in methanol [47]. Despite this, Schiff base derived from gabapentin and its $\mathrm{Co}(\mathrm{II}), \mathrm{Ni}(\mathrm{II}), \mathrm{Cu}(\mathrm{II})$ and $\mathrm{Zn}$ (II) complexes acted to inactive in ethanol [1]. From these results, it was seen that Schiff bases (1a3a) and (1b-3b) will be efficient DPPH radical scavengers in literature.

\subsection{Cytotoxicity Assay}

In vitro cytotoxicities of Schiff bases were investigated against two human cancer cell lines (HeLa and MCF-7), and a normal human cell line (HEK-293). Cells treated with EtOH were used as a solvent control.

The morphological changes in HeLa cancer cell were confirmed by phase contrast microscopy (Figure 3). From the results in Figure 4, it was noted that the monosodium-Schiff bases 1a-3a are less active cytotoxicity toward HeLa cell line with the cell-viability values between $80 \%$ and $87 \%$ in compared with doxorubicin. They showed dose-dependent antiproliferative effect within the concentration range of 100$10 \mu \mathrm{M}(\mathbf{1 a}), 100 \mu \mathrm{M}(\mathbf{2 a})$ and 100-1 $\mu \mathrm{M}$ (3a). The neutral-Schiff base 1b had low cytotoxicity toward HeLa cell line in the concentration range of 30-1 $\mu \mathrm{M}$ (98-88\% viability), while Schiff base $\mathbf{2 b}$ demonstrated inactivity (Figure 4a). Schiff base 3b increased the cell proliferation at concentration of $30 \mu \mathrm{M}$ and 100 $\mathrm{nM}$, but it behaved inactive between $10 \mu \mathrm{M}$ and $1 \mu \mathrm{M}$ (Figure $4 \mathrm{~b}$ ).
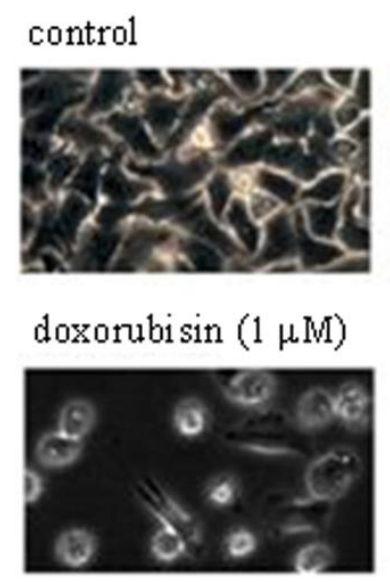
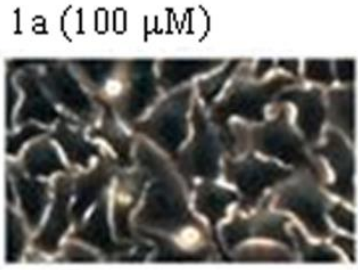

$1 b(30 \mu \mathrm{M})$

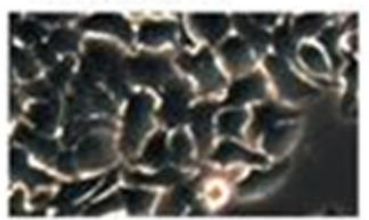

$2 \mathrm{a}(100 \mu \mathrm{M})$

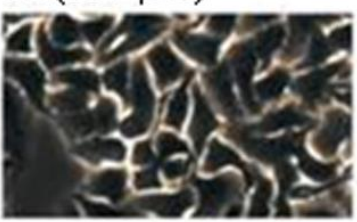

$2 b(100 \mu \mathrm{M})$

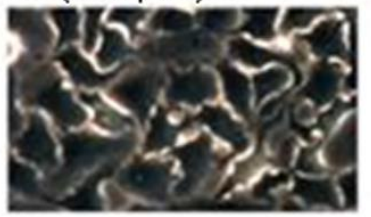

$3 \mathrm{a}(100 \mu \mathrm{M})$

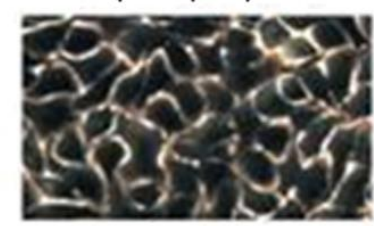

$3 \mathrm{~b}(30 \mu \mathrm{M})$

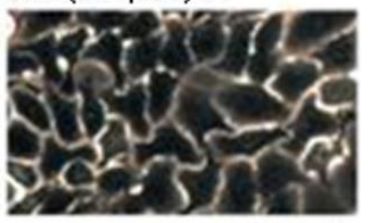

Figure 3. Phase contrast photographs of HeLa cells at 48 hours (x200) 

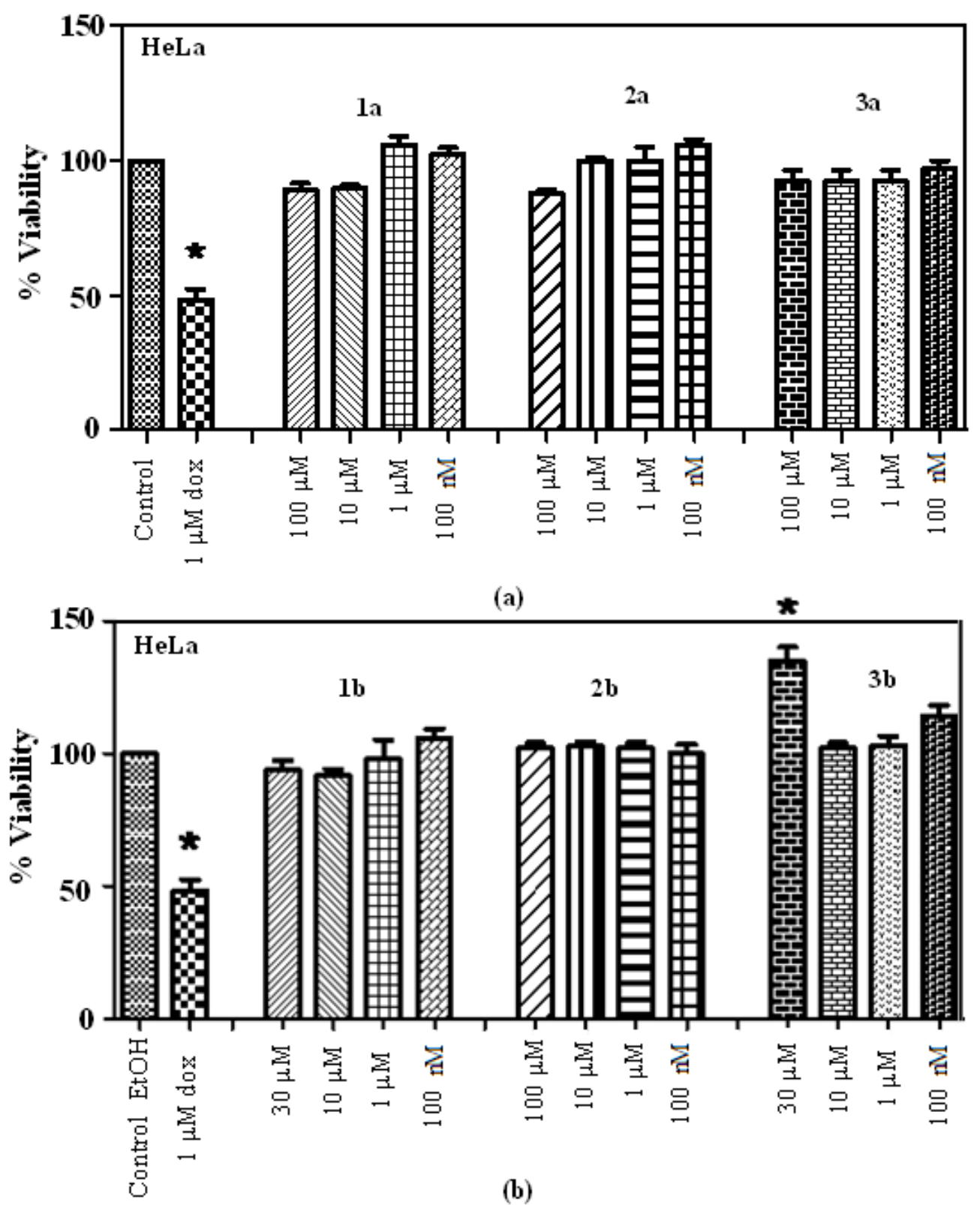

Figure 4. The evaluation of cytotoxic activity of Schiff bases against HeLa carcinoma cell line; a) the monosodium-Schiff bases (1a-3a), b) the neutral-Schiff bases $(\mathbf{1 b}-\mathbf{3 b})$. Dox, is Doxorubicin. * shows significant difference from control group. (One-way analysis of ANOVA, Tukey, $p<0.05, n=3$ )

The changes in MCF-7 cell line, which were pretreated with Schiff bases and doxorubicin were given in Figure 5. The monosodium-Schiff bases 1a and 3a showed no cytotoxicity against MCF-7 carcinoma cell line (Figure 6a) at concentration of $100 \mu \mathrm{M}$, however the cell proliferation increased with a decrease in their concentration. Schiff base 2a displayed the worst cytotoxicity against MCF-7. It caused a increase in the cell proliferation in the concentration range of $100 \mu \mathrm{M}-100 \mathrm{nM}$. Neutral-Schiff base $\mathbf{1 b}$ was inactive against MCF-7 between $30 \mu \mathrm{M}$ and $10 \mu \mathrm{M}$, but the concentration $\leq 1 \mu \mathrm{M}$, it slightly increased the viability of cell line. Schiff base $\mathbf{3 b}$ did not have any cytotoxicity within the concentration range of $30 \mu \mathrm{M}-100 \mathrm{nM}$ (Figure 6b). When tested against MCF-7 cell line, Schiff base $\mathbf{2 b}$ exhibited dual effect. This means that it achieved to inhibit the growth of carcinoma cell at high concentration, and failed to cause antiproliferation on cell at low concentration. At concentration of $100 \mu \mathrm{M}$, it showed very significant activity with the celldeath value of $90 \%$. But, it increased the cell proliferation at $1 \mu \mathrm{M}$ compared with that of doxorubicin (1 $\mu \mathrm{M}, 18 \%$ viability). 
control

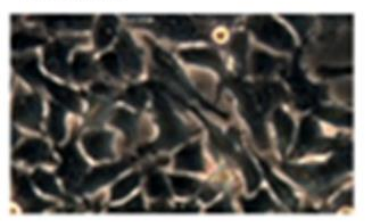

doxorubisin $(1 \mu \mathrm{M})$

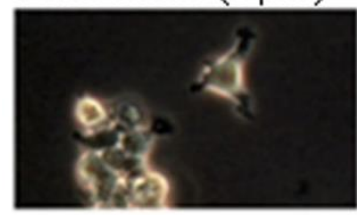

$1 \mathrm{a}(100 \mu \mathrm{M})$

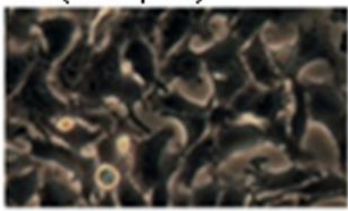

$1 \mathrm{~b}(30 \mu \mathrm{M})$

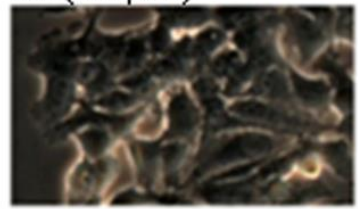

$2 \mathrm{a}(100 \mu \mathrm{M})$

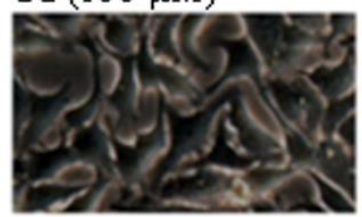

$2 \mathrm{~b}(100 \mu \mathrm{M})$

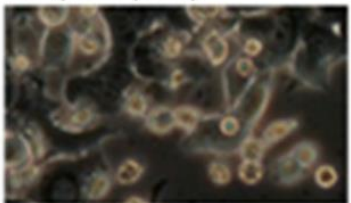

$3 a(100 \mu \mathrm{M})$

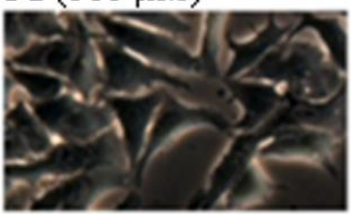

$3 b(30 \mu \mathrm{M})$

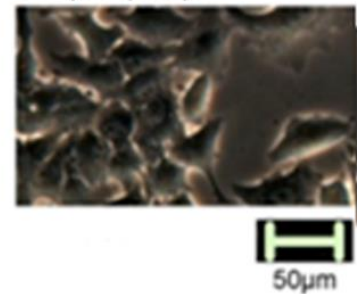

Figure 5. Phase contrast photographs of MCF-7 cells at 48 hours (x200)

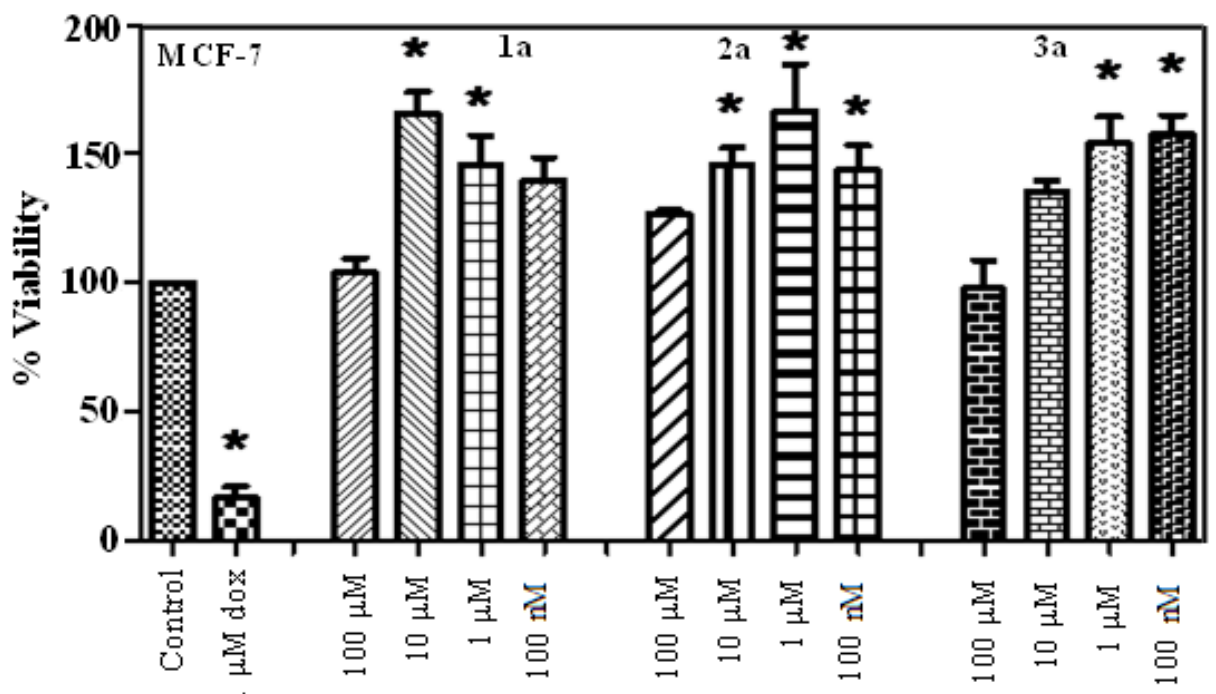

(a)

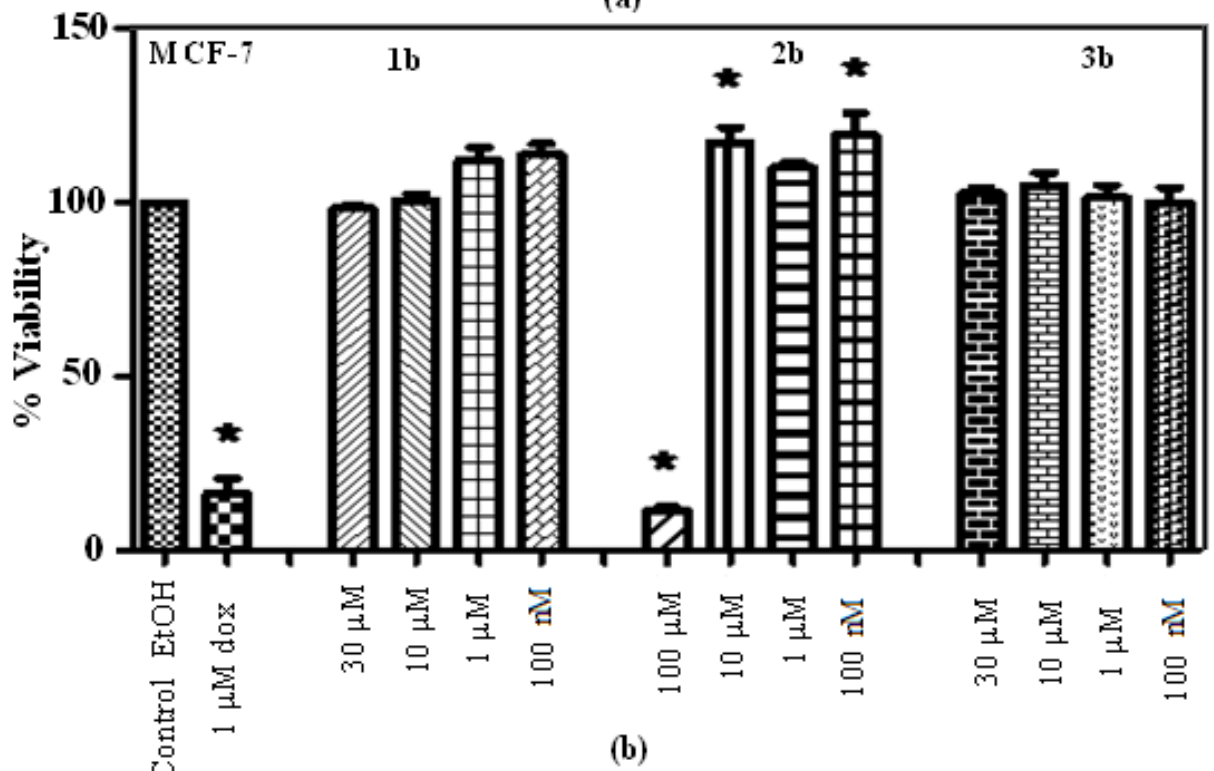

Figure 6. The evaluation of cytotoxic activity of Schiff bases against MCF-7 carcinoma cell line; a) the monosodium-Schiff bases (1a-3a), b) the neutral-Schiff bases (1b-3b). Dox, is Doxorubicin. * shows significant difference from control group. (One-way analysis of ANOVA, Tukey, $p<0.05, n=3$ ) 
In order to find the side-effect of Schiff bases on normal human cell line, their cytotoxicity against HEK293 cell line was also investigated under the same conditions. Microphotographs of HEK293 cell were presented in Figure 7. After treatment of the monosodium-Schiff bases, 1a did not show any toxicity at the concentration $\leq 10 \mu \mathrm{M}$ (Figure 8a). Schiff base 3a was not cytotoxic within the concentration range of 100 $\mu \mathrm{M}-100 \mathrm{nM}$. But, Schiff base 2a seemed to be anomalous in series, which has weak antiproliferative effect toward HEK293 cell line in the all dose range used $(100 \mu \mathrm{M}-100 \mathrm{nM})$. Interestingly, the neutral-Schiff base 1b displayed low toxicity against HEK293 above and below the concentration value of $1 \mu \mathrm{M}$ (Figure 8b). Schiff base $\mathbf{2 b}$ had lowest cytotoxic activity in the range of $100 \mu \mathrm{M}-1 \mu \mathrm{M}$. On the other hand, Schiff base 3b was found to be inactive between $30 \mu \mathrm{M}$ and $100 \mathrm{nM}$. In comparison to Schiff bases, doxorubicin showed the highest cytotoxicity against HEK293 cell with the $10 \%$ viability value at the concentration of $1 \mu \mathrm{M}$.
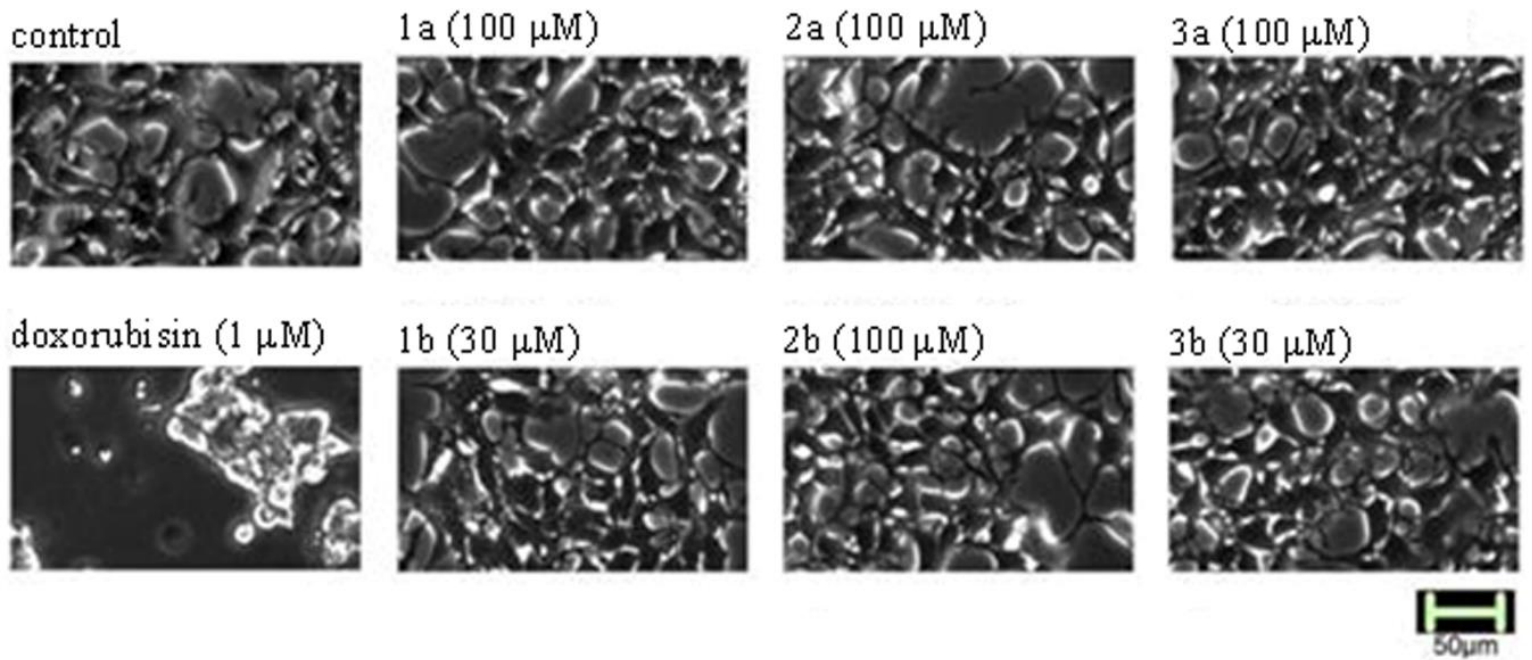

Figure 7. Phase contrast photographs of HEK-293 cells at 48 hours (x200)

Cytotoxicity assay results revealed that for HeLa cell, Schiff bases 1a-3a showed little high toxicity than $\mathbf{1 b}$, but very low toxicity than doxorubicin. Schiff bases $\mathbf{2 b}$ and $\mathbf{3 b}$ behaved inactive in the concentration range 10-1 $\mu \mathrm{M}$. It was appeared that Schiff bases $\mathbf{1 a}, \mathbf{3 a}, \mathbf{1 b}$ and $\mathbf{3 b}$ nearly have no cytotoxicity against MCF-7 cell at concentration of $100 \mu \mathrm{M}$, while $\mathbf{2 a}$ increases cell viability in the all tested concentration range. Surprisingly, Schiff base $\mathbf{2 b}$ presented very significant activity than other compounds, and killed 90 percent of MCF-7 cells at concentration of $100 \mu \mathrm{M}$. For a normal human cell line (HEK-293), doxorubicin could be classified as strongly cytotoxic. Despite this, Schiff bases 1a, 3a and $\mathbf{3 b}$ were inactive, whereas the others showed a very very weak toxicity.

According to literature survey, it could be noted that:

i. Antitumor activity of the compounds is dependent on both structure and dose [48].

ii. Less work has been reported for free amino acid Schiff bases exhibiting antitumor activity. Amino acids conjugated quinazolinone-Schiff's bases containing nitro group on the phenyl ring possessed moderate activity against MCF-7 cancer cell lines $\left(\mathrm{IC}_{50}=54.69-78.27 \mu \mathrm{g} / \mathrm{mL}\right)$ [9]. The $\mathrm{IC}_{50}$ value of Schiff base derived from alanine and 2,3-dihydroxybenzaldehyde was found to be $>100 \mu \mathrm{M}$ on human hepatocellular carcinoma cancer (HepG2) cell line [29]. On the other hand, Cu(II) complex of Schiff base ligand derived from thiophene-2-carboxaldehyde and l-histidine showed high activity on human ovarian cancer cells (PA1) $\left(\mathrm{IC}_{50}=91.42 \mu \mathrm{g} / \mathrm{mL}\right.$ ) compared to free ligand [49]. Novel Cd(II) complex of Schiff base obtained from 2-acetylpyridine and 1-tryptophan displayed high anti-proliferative effect on MDA-MB-231 breast cancer cells $\left(\mathrm{IC}_{50}=27 \mu \mathrm{mol} / \mathrm{L}\right)$, which was higher than that of cisplatin $\left(\mathrm{IC}_{50}\right.$ $=82 \mu \mathrm{mol} / \mathrm{L})[50]$.

iii. Cytotoxicity studies of Schiff bases based on higher amino acid molecules are not available in literature. From these results, it might be suggested that Schiff base $\mathbf{2 b}$ behaves to be a promising class of good MCF7 inhibitor in literature. 


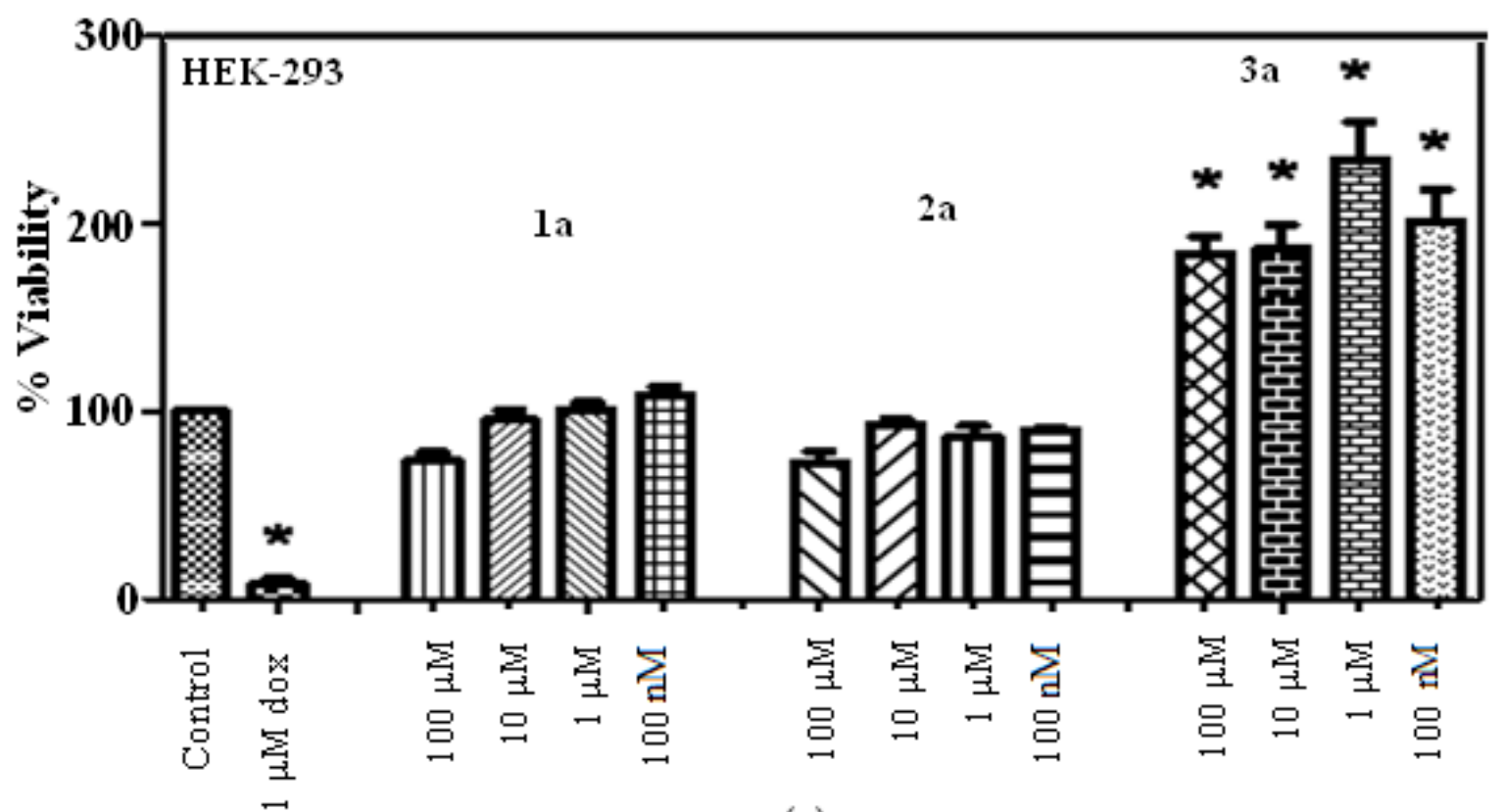

(a)

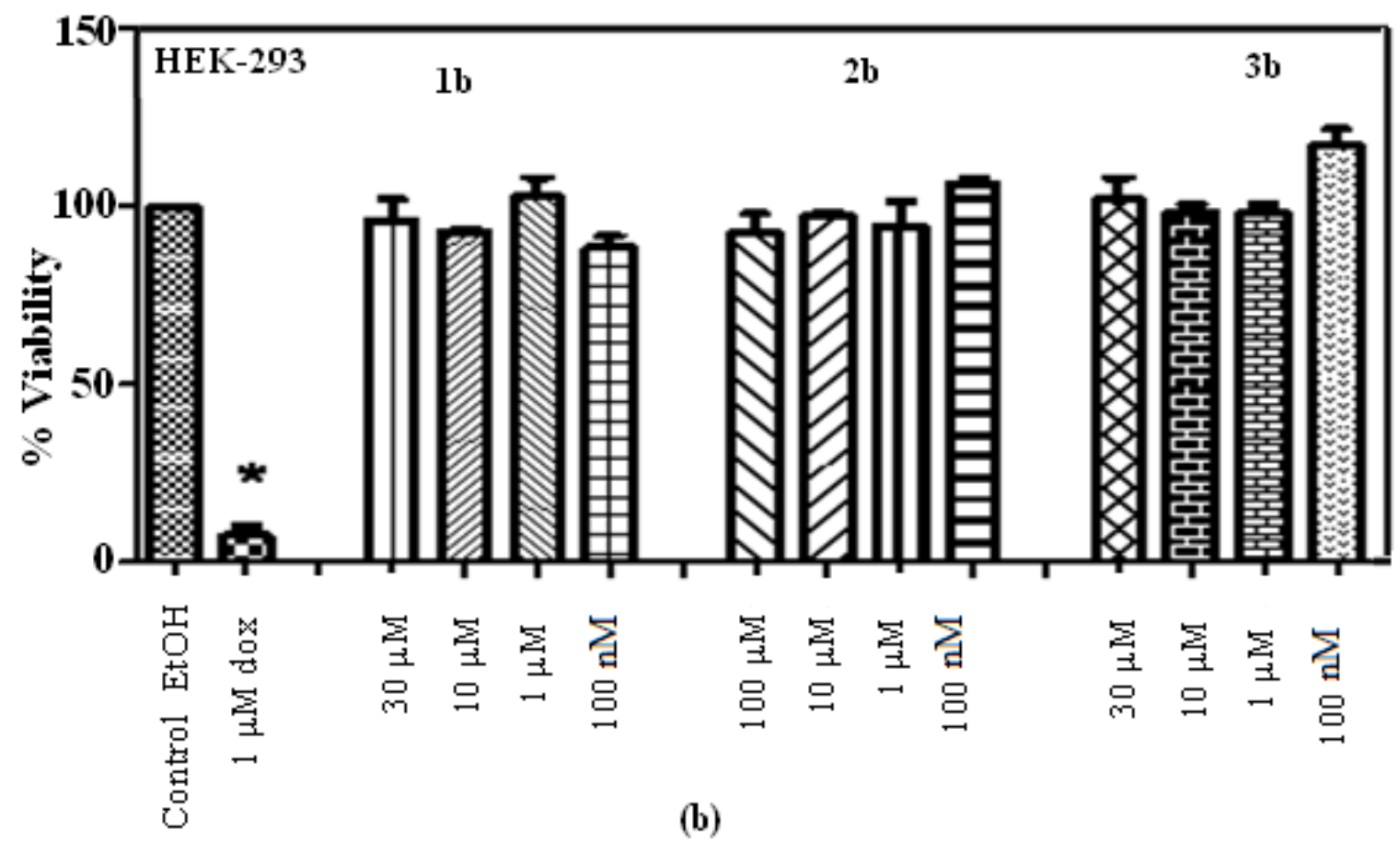

Figure 8. The evaluation of cytotoxic activity of Schiff bases against HEK-293 normal cell line; a) the monosodium-Schiff bases $(\mathbf{1} \boldsymbol{a}-3 \boldsymbol{a}), \boldsymbol{b})$ the neutral-Schiff bases $(\mathbf{1 b}-\mathbf{3 b})$. Dox, is Doxorubicin. * shows significant difference from control group. (One-way analysis of ANOVA, Tukey, $p<0.05, n=3$ )

\section{CONCLUSION}

In conclusion, the antioxidant activity of the monosodium-Schiff bases (1a-3a) and neutral-Schiff bases (1b-3b) was evaluated by DPPH assay. The results indicated that there was obvious correlation between DPPH free radical scavenging activity and the structure of ionic form of Schiff bases. 
In vitro cytotoxicities of these Schiff bases exhibited that no linear relationship between cytotoxicity and structure was obtained. The presence of ionic or neutral form or increase in the number of methylene groups did not lead to increase anticancer activity.

Lastly, it was hypothesized that a good antioxidant will have better antitumor activity. Despite the fact that the neutral-Schiff bases were effective scavengers of DPPH radical, this did not lead to an increase in their cytotoxicity toward HeLa cell. The cytotoxicity results of the monosodium Schiff bases showed that their antitumor activity may be positively affected by the radical scavenging ability. But, it was found that the viability values of cancer cell were not in line with the order of $\mathrm{SC}_{50}$ values of the compounds. On the other hand, none of the tested compounds, except $\mathbf{2 b}$, exhibited good cytotoxicity toward MCF-7 cells. In this case, it may be suggested that no clear correlation was observed between radical scavenging and antitumor activities of these Schiff bases.

\section{ACKNOWLEDGEMENTS}

We are thankful to Research Foundation of Gazi University for supporting this study with the project F.E.F.05/2011-24.

\section{CONFLICTS OF INTEREST}

No conflict of interest was declared by the authors.

\section{REFERENCES}

[1] Ikram, M., Rehman, S., Khan, A., Baker, R.J., Hofer, T.S., Subhan, F., Qayum, M., Faridoon, Schulzke C., "Synthesis, characterization, antioxidant and selective xanthine oxidase inhibitory studies of transition metal complexes of novel amino acid bearing Schiff base ligand", Inorganica Chimica Acta, 428: 117-126, (2015).

[2] Blois, M. S., "Antioxidant determination by the use of a free radical", Nature, 181: 1199-1200, (1958).

[3] Beena, K., D., Rawat, D. S., "Synthesis and antioxidant activity of thymol and carvacrol based Schiff bases", Bioorganic and Medicinal Chemistry Letters, 23: 641-645, (2013).

[4] Pillai, R. R., Karrouchi, K., Fettach, S., Armakovic, S., Armakovic, S. J., Brik, Y., Taoufik, J., Radi, S., My Faouzi, E. A., Ansar, M., "Synthesis, spectroscopic characterization, reactive properties by DFT calculations, molecular dynamics simulations and biological evaluation of Schiff bases tethered 1,2,4-triazole and pyrazole rings", Journal of Molecular Structure, 1177: 4754, (2019).

[5] Cantuti-Castelvetri, I., Shukitt-Hale, B., Joseph, J. A., "Neurobehavioral aspects of antioxidants in aging", International Journal of Development Neuroscience, 18: 367-381, (2000).

[6] Amarowicz, R., Peggb, R. B., Rahimi-Moghaddam, P., Barld, B., Weil, J. A., "Free-radical scavenging capacity and antioxidant activity of selected plant species from the Canadian prairies", Food Chemistry, 84: 551-562, (2004).

[7] Menteşe, E., Yılmaz, F., Baltaş, N., Bekircan, O., Kahveci, B., "Synthesis and antioxidant activities of some new triheterocyclic compounds containing benzimidazole, thiophene, and 1,2,4triazole rings", Journal of Enzym Inhibition and Medicinal Chemistry Early Online,1-7, (2014).

[8] Shanty, A. A., Mohanan, P. V., "Heterocyclic Schiff bases as nontoxic antioxidants: Solvent effect, structure activity relationship and mechanism of action", Spectrochimica Acta Part A: Molecular and Biomolecular Spectroscopy, 192: 181-187, (2018). 
[9] Rakesh, K. P., Kumara, H. K., Manukumar, H. M., Gowda, D. C., "Anticancer and DNA binding studies of potential amino acids based quinazolinone analogs: Synthesis, SAR and molecular docking", Bioorganic Chemistry, 87: 252-264, (2019).

[10] Chacko, S., Samanta, S., "A novel approach towards design, synthesis and evaluation of some Schiff base analogues of 2-aminopyridine and 2-aminobezothiazole against hepatocellular carcinoma", Biomedicine Pharmacotherapy, 89: 162-176, (2017).

[11] Shahraki, S., Delarami, H. S., Saeidifar, M., "Catalase inhibition by two Schiff base derivatives. Kinetics, thermodynamic and molecular docking studies", Journal of Molecular Liquid, 287: 111003, (2019).

[12] Ferri, N., Cazzaniga, S., Mazzarella, L., Curigliano, G., Lucchini, G., Zerla, D., Gandolfi, R., Facchetti, G., Pellizzoni, M., Rimoldi, I., "Cytotoxic effect of (1-methyl-1H-imidazol-2-yl)methanamine and its derivatives in $\mathrm{Pt}^{\mathrm{II}}$ complexes on human carcinoma cell lines: A comparative study with cisplatin", Bioorganic and Medicinal Chemistry, 21: 2379-2386, (2013).

[13] Ott, I., Gust, R., "Non Platinum Metal Complexes as Anti-cancer Drugs", Archiv der PharmazieChemistry Life Sciences, 340: 117-126, (2007).

[14] Kaldır, H. M., Tatlı, E., Turgut, B., Vural, Ö., "Doksorubisin’e Bağlı Kardiyotoksisite", Turkiye Klinikleri Journal of Cardiology, 15: 416-421, (2002).

[15] Jin, V. X., Ranford, J. D., "Complexes of platinum(II) or palladium(II) with 1,10-phenanthroline and amino acids", Inorganica Chimica Acta, 304: 38-44, (2000).

[16] Bakalova, A., Varbanov, H., Buyukliev, R., Stanchev, S., Momekov, G., Ivanov, D., "Novel Pt(II) and $\mathrm{Pt}(\mathrm{IV})$ complexes with 3-amino-5-methyl-5-(4-pyridyl)-2,4-imidazolidenedione. Synthesis, physicochemical, chemometric and pharmacological investigation", Inorganica Chimica Acta, 363: 1568-1576 (2010).

[17] Shahraki, S., Majd, M. H., Heydari, A., "Novel tetradentate Schiff base zinc(II) complex as a potential antioxidant and cancer chemotherapeutic agent: Insights from the photophysical and computational approach", Journal of Molecular Structure, 1177: 536-544, (2019).

[18] Özdemir, Ö., Gürkan, P., Sarı, M., Tunç, T., "Synthesis of monosodium salts of N-(5-nitrosalicylidene)-D-amino acid Schiff bases and their iron(III) complexes: spectral and physical characterizations, antioxidant activities", Journal of Coordination Chemistry, 68: 2565-2585, (2015).

[19] Wang, H., Yuan, H., Li, S., Li, Z., Jiang, M., "Synthesis, antimicrobial activity of Schiff base compounds of cinnamaldehyde and amino acids", Bioorganic and Medicinal Chemistry Letters, 26: 809-813, (2016).

[20] Ganguly, R., Sreenivasulu, B., Vittal, J., "Amino acid-containing reduced Schiff bases as the building blocks for metallasupramolecular structures", Coordination Chemistry Reviews, 252: 1027-1050, (2008).

[21] Soares, S. M., Lemos, S. S., Sales, M. J. A., Burrow, R. A., "On the nuclearity of tricarbonyl rhenium(I) complexes with N,O,O-donating Schiff bases derived from amino acids", Journal of Organometallic Chemistry, 750: 80-85, (2014). 
[22] Sevgi, F., Bagkesici, U., Kursunlu, A. N., Guler, E., "Fe (III), Co(II), Ni(II), Cu(II) and Zn(II) complexes of schiff bases based-on glycine and phenylalanine: Synthesis, magnetic/thermal properties and antimicrobial activity", Journal of Molecular Structure, 1154: 256-260, (2018).

[23] Abdel-Rahman, L. H., El-Khatib, R. M., Nassr, L. A. E., Abu-Dief, A. M., "DNA binding ability mode, spectroscopic studies, hydrophobicity, and in vitro antibacterial evaluation of some new Fe(II) complexes bearing ONO donors amino acid Schiff bases", Arabian Journal of Chemistry, 10: 1835-1846, (2017).

[24] Gupta, R., Mathur, M., Kumar Swami, A., Sharma, J., Singh, Y., "Synthesis and pharmacological activity of diorganoantimony(III) and triorganoantimony(V) derivatives of Schiff bases derived from amino acids", Journal of Saudi Chemical Society, 21: 67-75, (2017).

[25] Zhou, Y., Zhao, M., Wu, Y., Li, C., Wu, J., Zheng, M., Peng, L., Peng, S., "A class of novel Schiff's bases: Synthesis, therapeutic action for chronic pain, anti-inflammation and 3D QSAR analysis", Bioorganic and Medicinal Chemistry, 18: 2165-2172, (2010).

[26] Zheng, J., Ma, L., "Silver(I) complexes of 2,4-dihydroxybenzaldehyde-amino acid Schiff bases: Novel noncompetitive $\alpha$-glucosidase inhibitors", Bioorganic and Medicinal Chemistry Letters, 25 : 2156-2161, (2015).

[27] Wang, R. M., Mao, J. J., Song, J. F., Huo, C. X., He, Y. F., "Antioxidant activity of bovine serum albümin binding amino acid Schiff-bases metal complexes", Chinese Chemical Letters, 18: 1416$1418,(2007)$.

[28] Li, L-J., Fu, B., Qiao, Y., Wang, C., Huang, Y-Y., Liu, C-C., Tian, C., Du, J-L., "Synthesis, characterization and cytotoxicity studies of platinum(II) complexes with reduced amino acid ester Schiff-bases as ligands", Inorganica Chimica Acta, 419: 135-140, (2014).

[29] Alsalme, A., Laeeq, S., Dwivedi, S., Khan, M. S., Al Farhan, K., Musarrat, J., Khan, R. A., "Synthesis, characterization of $\alpha$-amino acid Schiff base derived $\mathrm{Ru} / \mathrm{Pt}$ complexes: Induces cytotoxicity in HepG2 cell via protein binding and ROS generation", Spectrochimica Acta Part A: Molecular and Biomolecular Spectroscopy, 163: 1-7, (2016).

[30] Muche, S., Harms, K., Biernasiuk, A., Malm, A., Popiolek, L., Hordyjewska, A., Olszewska, A., Holynska, M., "New Pd(II) schiff base complexes derived from ortho-vanillin and L-tyrosine or L-glutamic acid: Synthesis, characterization, crystal structures and biological properties", Polyhedron, 151: 465-477, (2018).

[31] Sallam, S. A., Orabi, A. S., Abbas, A. M., "DNA interaction with octahedral and square planar $\mathrm{Ni}(\mathrm{II})$ complexes of aspartic-acid Schiff-bases", Journal of Molecular Structure, 1006: 272-281, (2011).

[32] Shahraki, S., Shiri, F., Saeidifar, M., "Evaluation of in silico ADMET analysis and human serum albumin interactions of a new lanthanum(III) complex by spectroscopic and molecular modeling studies", Inorganica Chimica Acta, 463: 80-87, (2017).

[33] Mahmood, S., Malik, M. A., Motevalli, M., Nunn, P. B., Q’Brien, P., "Synthesis and X-ray crystal structures of Schiff bases prepared from salicylaldehyde and the diamino acids L-2-amino-3methylaminopropanoic acid, DL-2,4-diamino-butanoic acid and DL-2,3-diaminopropanoic acid", Tetrahedron, 54: 5721-5730, (1998).

[34] Yang, C. T., Vittal, J. J., "Synthesis and structural behavior of ternary copper(II) complexes containing reduced Schiff base $\mathrm{N}$-(2-hydroxybenzyl)-4-aminobutyric acid and 1,10phenanthroline", Inorganica Chimica Acta, 344: 65-76, (2003). 
[35] Puterova, Z., Valentova, J., Bojkova, Z., Kozisek, J., Devinsky, F., "Synthesis, crystal structure and antiradical effect of copper(II) Schiff base complexes containing five-, six- and unusual sevenmembered rings", Dalton Transactions, 40: 1484-1490, (2011).

[36] Güngör, Ö., Gürkan, P., "Synthesis and characterization of higher amino acid Schiff bases, as monosodium salts and neutral forms. Investigation of the intramolecular hydrogen bonding in all Schiff bases, antibacterial and antifungal activities of neutral forms", Journal of Molecular Structure, 1074: 62-70, (2014).

[37] Özdemir, Ö., "Studies on phenol-keto tautomerism, metal ion binding, and free radical scavenging properties of newly synthesized naphthalene-based tetraimine", Journal of BAUN Institute of Science and Technology, 20: 109-123, (2018).

[38] Özdemir, A., Şimay, Y. D., İbişoğlu, B., Yaren, B., Bülbül, D., Ark, M. "Cardiac glycosideinduced cell death and Rho/Rho kinase pathway: Implication of different regulation in cancer cell lines", Steroids, 109: 29-43, (2016).

[39] Zhang, Y., Fang, Y., Liang, H., Wang, H., Hu, K., Liu, X., Yi, X., Peng, Y., "Synthesis and antioxidant activities of 2-oxo-quinoline-3-carbaldehyde Schiff-base derivatives", Bioorganic and Medicinal Chemistry Letters, 23: 107-111, (2013).

[40] Porter, W. L., Antioxidants: Chemical, Physiological, Nutritional and Toxicological Aspects, (Williams,G.M.), Easton, USA, 93-122,(1993).

[41] Nenadis, N., Wang, L-F., Tsimidou, M., Zhang, H-Y., "Estimation of Scavenging Activity of Phenolic Compounds Using the ABTS ${ }^{+}$Assay", Journal of Agricultural and Food Chemistry, 52: 4669-4674, (2004).

[42] Sharma, O. P., Bhat, T. K., "DPPH antioxidant assay revisited", Food Chemistry, 113: 1202-1205, (2009).

[43] Sathiyaraj, S., Sampath, K., Butcher, R. J., Pallepogu, R., Jayabalakrishnan, C., "Designing, structural elucidation, comparison of DNA binding, cleavage, radical scavenging activity and anticancer activity of copper(I) complex with 5-dimethyl-2-phenyl-4-[(pyridin-2-ylmethylene)amino]-1,2-dihydro-pyrazol-3-one Schiff base ligand", European Journal of Medicinal Chemistry, 64: 81-89, (2013).

[44] Brand-Williams, W., Cuvelier, M. E., Berset, C., "Use of a free radical method to evaluate antioxidant activity", Lebensmittel-Wissenschaft und Technologie, 28: 25-30, (1995).

[45] Thalamuthu, S., Annaraj, B., Neelakantan, M. A., "A systematic investigation on biological activities of a novel double zwitterionic Schiff base Cu(II) complex", Spectrochimica Acta Part A: Molecular and Biomolecular Spectroscopy, 118: 120-129, (2014).

[46] Ratha, P., Chitra, L., Ancy, I., Kumaradhas, P., Palvannan, T., "New amino acid-Schiff base derived from s-allyl cysteine and methionine alleviates carbon tetrachloride-induced liver dysfunction", Biochimie, 138: 70-81, (2017).

[47] Adam, M. S. S., Elsawy, H., "Biological potential of oxo-vanadium salicylediene amino-acid complexes as cytotoxic, antimicrobial, antioxidant and DNA interaction", Journal of Photochemistry and Photobiology B, 184: 34-43, (2018). 
[48] Özdemir, Ö., Gürkan, P., Şimay Demir, Y.D., Ark, M., "Novel palladium(II) complexes of N-(5nitro-salicylidene)-Schiff bases: Synthesis, spectroscopic characterization and cytotoxicity investigation", Journal of Molecular Structure, 1207: 127852, (2020).

[49] John, L., Dasan, A., Joseyphus, R. S., Joe, I. H., "Molecular docking, structural characterization, DFT and cytotoxicity studies of metal(II) Schiff base complexes derived from thiophene-2carboxaldehyde and 1-histidine", Journal of Molecular Structure, 1198: 126934, (2019).

[50] Zhang, N., Fan, Y-h., Zhang, Z., Zuo, J., Zhang, P-f., Wang, Q., Liu, S-b., Bi, C-f., Syntheses, crystal structures and anticancer activities of three novel transition metal complexes with Schiff base derived from 2-acetylpyridine and l-tryptophan, Inorganic Chemistry Communications, 22: 68-72, (2012). 